\title{
RŪKYMO IR ŠIZOFRENIJOS RYŠYS: PRIEŽASTYS IR PASEKMĖS
}

\author{
Giedrius Šẻmys \\ Vilniaus universiteto Medicinos fakultetas
}

Raktažodžiai: rūkymas, šizofrenija, koreliacija, priežastys, pasekmès, antipsichotikai, metabolizmas.

\section{Santrauka}

Rūkymas daro didžiulị neigiamą poveikị visuomenès sveikatai ir yra ypač paplitęs tarp įvairiomis psichikos ligomis sergančių asmenų. Egzistuoja nemažai teorijų, bandančių paaiškinti rūkymo ir šizofrenijos sąsają, tačiau kol kas nenustatytos tikslios priežastys, paaiškinančios ši ryšį. Manoma, kad rūkymo paplitimą tarp šizofrenija sergančių asmenų didina genetiniai, aplinkos bei socialiniai veiksniai. Rūkymo sukeliama žala šizofrenija sergančiu asmenų populiacijoje ypač didelè dèl ryškios šiu asmenų patiriamos socialinės atskirties, mažų pajamų, nepasitikèjimo gydytojais ir sveikatos apsaugos sistema. Rūkymas indukuoja kai kurių fermentų, metabolizuojančių antipsichotinius vaistus, sintezę ir gali sukelti nepakankamą šiu vaistų poveikị, gydant šizofreniją. Svarbu ị tai atsižvelgti ir rūkantiems asmenims skirti didesnes vaistų dozes arba rinktis vaistus, kurių metabolizmo rūkymas neveikia. Tyrimo tikslas - ivvertinti ir aptarti mokslinejje literatūroje pateikiamas priežastis, dèl kurių rūkymas paplitęs tarp šizofrenija sergančių asmenų, bei jų dẻl rūkymo patiriamas neigiamas sveikatos pasekmes.

\section{Ivadas}

Rūkymas yra viena iš opiausių šiandieninès visuomenès sveikatos problemų. PSO duomenimis, per 1,3 mlrd. žmonių visame pasaulyje rūko tabako gaminius [1]. Rūkymas yra didžiule problema ir psichiatrinių pacientu populiacijoje: 45-70 proc. psichikos sutrikimus turinčių asmenų rūko [2]. Ši problema ypač pastebima tarp šizofrenija sergančių asmenų, nes kai kurių tyrimų duomenimis, apie 90 proc. šių pacientų rūko [2]. Neigiama rūkymo įtaka širdies ir kraujagyslių, kvėpavimo, bei daugeliui kitų sistemų yra gerai žinoma, tačiau sergantiems šizofrenija rūkymas turi ir kitų neigiamų pasekmių: skatina somatinių ligų atsiradimą, kurios neigiamai veikia psichinę būseną, gali sumenkinti vartojamų antipsichotinių vaistų efektyvumą [3].
Tyrimo tikslas - išanalizuoti bei aptarti ịrodymais pagrịstą informaciją apie tabako rūkymo ir šizofrenijos tarpusavio ryši, rūkymo priežastis bei pasekmes šizofrenija sergantiems asmenims.

\section{Tyrimo medžiaga ir metodai}

Taikyta sisteminè mokslinès literatūros apžvalga ir analizè. Duomenų buvo ieškoma PubMed, Google Scholar, UpToDate bei Cochrane duomenų bazèse. Visateksčiai straipsniai atrinkti, jei jų pavadinimas, santrauka ar reikšminiai žodžiai nurode, kad tyrimas tinkamas šiai apžvalgai. Naudoti raktažodžiai: smoking, schizophrenia, correlation, causes, consequences, antipsychotics, metabolism.

\section{Tyrimo rezultatai}

Šizofrenija - polietiologinè psichinè liga. Susirgimui šizofrenija ịtakos turi įvairūs biologiniai veiksniai, genetinè predispozicija bei aplinkos veiksnių sąveika su organizmu. Nèra visiškai aišku, kas nulemia asmens susirgimą šizofrenija. Yra duomenų, kad motinos rūkymas perinataliniu periodu statistiškai reikšmingai padidina vaiko tikimybę susirgti šizofrenija sulaukus suaugusiojo amžiaus. Ypač ryški koreliacija su aukšta nikotino metabolito kotinino koncentracija motinos kraujo serume néštumo metu [3]. Manoma, kad tai skatina vaisiaus smegenų vystymosi pokyčius, kurie vèliau gali sukelti šizofreniją. Išskiriamos trys pagrindinès teorijos, nusakančios rūkymo ir šizofrenijos santykị: 1) rūkymas gali būti susirgimo šizofrenija priežastis, 2) šizofrenija gali skatinti priklausomybę nikotinui (pvz., pacientui rūkant savigydos tikslais ar siekiant nusiraminti), 3) galimi bendri genetiniai ir aplinkos rizikos veiksniai, predisponuojantys ir šizofreniją, ir priklausomybę nuo nikotino [4]. Šios teorijos nèra vienas kitą paneigiančios, tačiau dar ne visiškai aišku, kuri iš jų yra svarbiausia ir kokia jų tarpusavio sąveika.

Yra ir daugiau priežasčių, dèl kurių sergantieji šizofrenija labiau linkę i priklausomybę nuo nikotino, nei kita populiacijos dalis. Sergantieji šizofrenija turi mažiau žinių apie rūkymo žalą, nei sveiki asmenys, todèl svarbu paklausti pacientų nuomonès apie rūkymą, jo žalą bei naudą, taikyti 
mokymo priemones ir išsamiai supažindinti juos su rūkymo žala [5]. Kasdieniame gyvenime šizofrenija sergantys pacientai dažniau jaučiasi atstumti visuomenès, nesuprasti, dèl ligos simptomų (ivvairaus pobūdžio haliucinacijos, kliedesiai, anhedonija) patiria daugiau streso nei sveikieji, todèl renkasi rūkymą kaip savigydos būdą, siekdami numalšinti neigiamas emocijas [6]. Gydymo įstaigose susipažinę ir bendraudami su šizofrenija sergančiais asmenimis, iš kurių didžioji dauguma yra rūkantys, pacientai gali jausti socialinị spaudimą ir perimti ši ịprotị.

Rūkymo žala sveikatai yra gerai ištirta. Rūkančiujų 11 kartų didesnė rizika susirgti plaučiu vėžiu, nei nerūkančiųjų. Rūkant didejja insulto, infarkto ir onkologinių ligų rizika [5]. Pastebèta, kad šizofrenija sergantys pacientai rūko intensyviau, nei ja nesergantys rūkantieji - tai svarbi gyvenimo trukmès netolygumų priežastis, lyginant su bendra populiacija. Jungtinèse Amerikos Valstijose sergantieji šizofrenija miršta vidutiniškai 28 metais anksčiau, nei kiti asmenys [7]. İtakos turi daug veiksnių, tarp jų ir savižudybè. Rūkymo sukeltos kardiovaskulinės ir onkologinès ligos turi didžiulę itaką tokių netolygumų atsiradimui. Šizofrenija sergantys pacientai dẻl savo ligos dažnai būna socialiai izoliuoti, turintys mažiau pajamų, mažiau linkę kreiptis ị gydytojus, todèl gerokai sumažeja jų galimybės laiku gauti reikiamą medicininę pagalbą. Rūkymas yra vienas iš svarbiausių veiksnių, didinančių sergančiųų šizofrenija mirtingumą [8].

Specifine problema, kurią patiria šizofrenija sergantys rūkantieji - sumažèjęs antipsichotinių vaistų efektyvumas. Citochromas P450 1A2 yra pagrindinis fermentas, atsakingas už atipinių antipsichotikų olanzapino bei klozapino metabolizmą organizme. Pastebèta, kad rūkymas indukuoja šio fermento sintezę, todèl rūkantiems asmenims reikalingos didesnès nei ịprastinès šių vaistų dozès ir, metus rūkyti, svarbu atitinkamai mažinti dozę, kad būtų išvengta vaistų sukelto toksiškumo: rūkant šiu vaistų klirensas padidejja iki 50 procentų [5]. Rūkymas keičia ne visų vaistų efektyvumą, pavyzdžiui, kvetiapino koncentracija kraujo serume rūkant nekinta. Skiriant minètus vaistus, reikia įvertinti paciento rūkymo ịpročius, kad būtu paskirta tinkama dozè pasiekti terapini poveikị. Svarbu stebėti rūkančiu pacientų būklę, individualiai dozuoti minètus vaistus, vertinti jų klinikinį efektyvumą, arba rinktis kitus, kurių poveikio rūkymas nekeičia.

\section{Išvados}

1. Rūkymas yra ypač aktuali sergančiųų šizofrenija sveikatos problema. Beveik 90 proc. šizofrenija sergančiu asmenų rūko. Yra keletas teorijų, bandžiusių paaiškinti rūkymo paplitimą tarp šių pacientų, tačiau kol kas tiksli priežastis nenustatyta.

2. Rūkymo sukeltos neigiamos sveikatos pasekmès smarkiai prisideda prie gyvenimo trukmės netolygumų tarp šizofrenija sergančių asmenų ir bendrosios populiacijos.

3. Rūkymas neigiamai veikia kai kurių šizofrenijai gydyti naudojamų antipsichotinių vaistų efektyvumą, indukuodamas juos metabolizuojančių fermentų sintezę. Gydant rūkančius pacientus, reikia tinkamai koreguoti dozes arba skirti antipsichotinius vaistus, kurių efektyvumo rūkymas neveikia.

\section{Literatūra}

1. WHO. Tobacco. 2021. https://www.who.int/news-room/factsheets/detail/tobacco

2. Lohr JB, Flynn K. Smoking and schizophrenia. Schizophr Res 1992;8(2):93-102.

https://doi.org/10.1016/0920-9964(92)90024-Y

3. Sagud M, Mihaljević-Peles A, Mück-Seler D, Pivac N, VuksanCusa B, Brataljenović T, et al. Smoking and schizophrenia. Psychiatr Danub 2009;21(3):371-5.

4. Hartz SM, Horton AC, Hancock DB, Baker TB, Caporaso NE, Chen L-S, et al. Genetic correlation between smoking behaviors and schizophrenia. Schizophr Res 2018;194:86-90.

https://doi.org/10.1016/j.schres.2017.02.022

5. Šagud M, Vuksan-Ćusa B, Jakšić N, Mihaljević-Peleš A, Rojnić Kuzman M, Pivac N. Smoking in schizophrenia: an updated review. Psychiatr Danub 2018;30(Suppl 4):216-23.

6. Dutescu MM, Popescu RE, Balcu L, Duica LC, Strunoiu LM, Alexandru DO, Pîrlog MC. Social functioning in schizophrenia clinical correlations. Curr Health Sci J 2018;44(2):151-6.

7. Cather C, Pachas GN, Cieslak KM, Evins AE. Achieving smoking cessation in individuals with schizophrenia: special considerations. CNS Drugs 2017;31(6):471-81.

https://doi.org/10.1007/s40263-017-0438-8

8. Tidey JW, Miller ME. Smoking cessation and reduction in people with chronic mental illness. BMJ 2015;351:h4065.

https://doi.org/10.1136/bmj.h4065

\section{THE CORRELATION BETWEEN SMOKING AND SCHIZOPHRENIA: CAUSES AND CONSEQUENCES G. Šėmys}

Keywords: smoking, schizophrenia, correlation, causes, consequences, antipsychotics, metabolism.

Summary

Smoking is associated with a significant negative effect on public health and is especially prevalent among the mentally ill. The prevalence of smoking is especially pronounced among schizophrenia patients. Many theories exist that try to explain the connection between smoking and schizophrenia, however, its exact cause is yet to be determined. It is generally considered that genetic, environmental, and social factors all contribute to the prevalence of smoking among schizophrenia patients. The deleterious effects of smoking on health are particularly severe in this patient group due to widespread social isolation, low income, and distrust in physi- 
cians and the health system. Smoking induces the synthesis of enzymes that metabolise some antipsychotic agents and may result in insufficient therapeutic effects when affected drugs are used in standard doses. It is important to increase the dosage accordingly or to choose different antipsychotic agents whose metabolism is not affected by smoking. The aim of this study is to evaluate and analyse the data presented in the scientific literature on the reasons for the high prevalence of smoking in schizophrenia patients and the negative impact of smoking on their health.

Conclusions: 1. Smoking is especially prevalent among schizophrenia patients, of which around $90 \%$ smoke. Several theories exist that try to explain the connection between smoking and schizophrenia, however, an exact cause is yet to be determined. 2. Adverse health effects caused by smoking significantly contribute to life expectancy inequalities between schizophrenia patients and the general population. 3. Smoking increases the metabolism of certain antipsychotic agents. This should be accounted for by either increasing the dosage or by choosing antipsychotic agents whose metabolism is not affected by smoking.

Correspondence to: giedrius.semys@gmail.com

Gauta 2021-04-22 